\title{
The Role of Digital Servitization in Transition Economy: An SNA Approach
}

\author{
Nikola ZIVLAK, Slavko RAKIC, Ugljesa MARJANOVIC, Danijela CIRIC, Branislav BOGOJEVIC*
}

\begin{abstract}
Digital servitization changes the way in which manufacturing firms offer their traditional products. Digital services support manufacturing firms to transform their product-oriented business models to service-oriented business models. Additionally, digital servitization affects manufacturing firms to offer digital solutions for their customers. According to this influence, the manufacturing firms change their ecosystems with the transition from product-oriented services to digital solutions. This paper investigates the ecosystem transformation of manufacturing firms. The current dataset includes 690 observations of manufacturing firms from the Republic of Serbia in the period of five years. The trend of the use of digital services in manufacturing firms was evaluated using a Social Network Analysis. The empirical results indicate that manufacturing firms from transition economies increased the use of digital services by $20 \%$ from 2015 to 2020 .
\end{abstract}

Keywords: digital servitization; digital services; manufacturing firms; product-related services; social network analysis

\section{INTRODUCTION}

The first evidence from 2007 in the global research on the application of servitization shows the different use of traditional services between transition and developed economies [1]. Moreover, previous research shows that countries that based their economy on pure manufacture had lower opportunities to apply advanced services along with products [1]. However, the second evidence from 2011 shows that some of the transition economies in this period (i.e. China) made the biggest progress in the application of servitization in manufacturing firms [1]. China made the growth of $20 \%$ in the period of four years in the implementation of servitization in the manufacturing firms [2]. These changes influence the existence of new business models for manufacturing firms which results in higher GDP [2]. After ten years, we can see that China is transformed from transition to the developed economy by the implementation of innovation in the ecosystems of their manufacturing firms [2]. Moreover, China is an example of how to implement the successful transformation of manufacturing firms in the era of Industry 4.0 [3]. These results are reflected in the last global evidence of the servitization application, which shows that transition economies from previous research (i.e. China and Brazil) now are on the list of developed economies with $39 \%$ of servitised firms in China and $26 \%$ of servitised firms in Brazil [4]. On the other side, the leaders in the application of servitization between developed countries during the years are the USA, Australia, and the UK [4]. Different from the transition economies ten years ago, today's transition economies strive to successfully implement servitization with the help of digital technologies $[5,6]$. Unfortunately, the level of the use of services in manufacturing firms from transition economies today (i.e. Republic of Serbia) is on the level of developed economies ten years ago $[5,1]$. Furthermore, the Republic of Serbia is in a similar situation as China in 2011, when China based its manufacture only on pure products [2,7]. Additionally, the level of the application of Industry 4.0 concepts is on a low level in the transition economies $[6,7]$. The low application of digital technologies is one of the main obstacles to the successful implementation of digital services in manufacturing firms [3]. However, the research from developed economies shows many positive examples between manufacturing firms in how they implement digital servitization $[8,9]$. The successful implementation of digital servitization results in positive financial implications, which increase firm competitiveness and performance [10]. The application of digital technologies enables manufacturing firms to offer new digital solutions for their customers [11, 12]. Far from developed economies, research in developing countries has measured only the impact of digital servitization on firms' performance, while the role of traditional and digital services in manufacturing ecosystems remains neglected $[5,6]$. It remains unclear how small transition economies can achieve the level of servitization of developed countries.

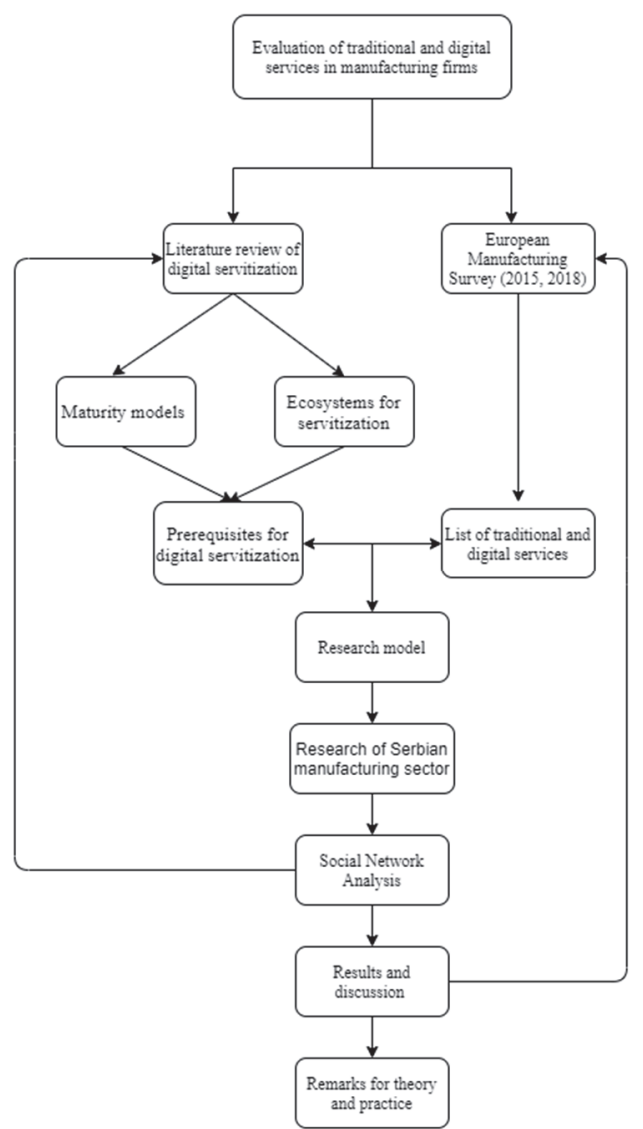

Figure 1 Model for evaluation of traditional and digital services in manufacturing firms 
Furthermore, the strategic view of the implementation of digital servitization in transition economies still neglected [13]. This gap in the literature makes a misunderstanding in the way how the transition economies could become a part of the value chain of developed economies. Accordingly, the aim of this paper is to investigate which traditional and digital services make the highest impact on the ecosystem of manufacturing firms.

Therefore, this brings the following research questions:

- RQ1: Which traditional services make the highest effect on the ecosystem of manufacturing firms?

- RQ2: Which digital services make the highest effect on the ecosystem of manufacturing firms?

According to the needs, problem, and aim of the research, the authors developed the model for the evaluation of traditional and digital services. Fig. 1 depicts the evaluation process, research methods, and data analysis.

The manuscript is structured as follows: Section 2 presents the literature background. Section 3 describes the sample, data collection, and social network analysis method. Section 4 presents the empirical results of the research. In addition, section 5 summarises practical and theoretical implications. Finally, section 6 depicts the conclusions with their limitations and suggestions for further research.

\section{LITERATURE REVIEW}

Digital servitization is the application of digital technologies in the traditional offers of product-related services [11]. Product-related services are traditional services that are offered by manufacturing firms along with products. [14]. Furthermore, the Tukker model of transformation of product-service systems shows three service orientations: product-oriented, use-oriented, and results-oriented [14]. According to this classification, digital services represent the last step in the transformation of manufacturing firms [6,5]. Digital services enable manufacturing firms to offer digital solutions for their customers [6, 8] while digital solutions enable manufacturing firms to create a competitive advantage in the marketplace [15]. However, many manufacturing firms from transition economies still do not understand the mechanisms for the implementation of digital servitization [16]. The research of maturity model shows customer experience, strategy, business processes, organization, and culture as the main components of successful implementation of digital servitization [16]. Additionally, researches present the existence of the digital ecosystems of manufacturing firms as a necessary prerequisite for a successful application of digital services [17]. The application of digital services requires the connection between the central organization of firms and service departments [17]. The management of the firms needs to encourage the digitalization process in a way to enable service departments to involve software platforms in their business [17]. Moreover, research shows that manufacturing firms need to have an IT department that would be in interaction with production managers to enable digital solutions for customers [18]. Digital technologies such as big-data analysis, augmented or virtual reality, and artificial intelligence, are technologies that transform traditional to advanced digital services [7, 15, 17]. With these technologies, the management of manufacturing firms could produce new knowledge, skills, and tools about digital servitization [19]. The understanding of digital competencies is necessary for the ecosystems of manufacturing firms [9, 19]. The knowledge, skills, and attitudes about digital servitization are the main difference between more or less successful firms [4]. Furthermore, the management of manufacturing firms from developed economies is aware of the importance of digital servitization for manufacturing firms [8]. Developed economies transform their manufacturing sector according to the concepts of Industry 4.0 [8]. Unlike developed economies, the transition economies do not understand the importance of the Industry 4.0 concepts for manufacturing firms [8]. This misunderstanding of the concepts of Industry 4.0 prevents firms from transition economies to develop a strategy for digital servitization [6, 17]. Accordingly, there are no reasons why some manufacturing firms from transition economies use certain services [7]. Therefore, the success of the implementation of digital servitization is not on the sector strategy level but on the individual firm level, without the existence of ecosystems $[15,4]$. These shortcomings are the reason why developed economies achieve better results in the implementation of digital servitization than transition economies [13]. Moreover, the comparative analysis shows that manufacturing firms from developed economies have a higher impact on financial performance than firms from transition economies [15, 20]. Additionally, findings show that firms without servitization strategy are on the brink of increased bankruptcy risks for the firm [13]. Hence, the ecosystem of the manufacturing firms has appeared to have an important possibility for controlling the risk consequences in the service and digital transformation of the firm [13]. The previous research shows that digital platforms for production service systems should be introduced to overcome these barriers [21]. The digital platforms approach supports the reducing cost for manufacturing firms in transition economies [21]. The existence of digital platforms and ecosystems is necessary for firms from transition economies to be part of the value chains of developed economies [18, 27]. Therefore, research from China in 2007 could serve as a guide to the successful implementation of innovation through servitization [3]. Moreover, the influence from the government of transition economies is necessary to raise awareness of the importance of digital servitization for both the company and the economy of the country $[16,21]$. According to this background, the study examines the most important traditional and digital services in the firm's networks.

\section{METHODOLOGY}

\subsection{Sample and Data Collection}

The data for this research were collected from the manufacturing sector of the Republic of Serbia through the European Manufacturing Survey [22], coordinated by the Fraunhofer ISI from Germany. According to the aim of this research, the manufacturing sector of the Republic of Serbia is chosen for the population to represent the 
transition economies. The sample was obtained by the method of determining the stratified sample in relation to the industrial sector, the size of the company, and the district in the Republic of Serbia. The research was conducted within manufacturing firms with at least 20 employees. Respondents during the research were production managers. The response rate was about $34 \%$. Tab. 1 shows the firm size.

Table 1 Distribution of sample by firm size

\begin{tabular}{|c|c|c|}
\hline Firm size & $n$ & $\%$ \\
\hline 20 to 49 employees & 266 & 38.6 \\
\hline 50 to 249 employees & 318 & 46.1 \\
\hline 250 and more employees & 106 & 15.4 \\
\hline
\end{tabular}

Approximately $38.6 \%$ of the firms in the sample are small, having between 20 and 49 employees, while the other $46.1 \%$ of the firms have between 50 and 249 employees, and $15.4 \%$ more than 250 employees. Tab. 2 depicts the sample by industry.

The largest industries in the sample are the manufacture of food products (NACE 10) with 17.3\%, followed by the production of fabricated metal products, except machinery and equipment (NACE 25) with 10.9\%, and the manufacture of machinery and equipment n.e.c. (NACE 28) with $7.1 \%$.

Table 2 Distribution of sample by industry

\begin{tabular}{|c|c|}
\hline Manufacturing industry & Share on total sample \\
\hline Manufacture of food products & $17.3 \%$ \\
\hline $\begin{array}{c}\text { Manufacture of fabricated metal products, } \\
\text { except machinery and equipment }\end{array}$ & $10.9 \%$ \\
\hline $\begin{array}{c}\text { Manufacture of machinery and equipment } \\
\text { n.e.c }\end{array}$ & $7.1 \%$ \\
\hline Manufacture of rubber and plastic products & $6.6 \%$ \\
\hline Manufacture of electrical equipment & $6.4 \%$ \\
\hline $\begin{array}{c}\text { Manufacture of wood and of products of wood } \\
\text { and cork }\end{array}$ & $5.1 \%$ \\
\hline $\begin{array}{c}\text { Manufacture of other non-metallic mineral } \\
\text { products }\end{array}$ & $4.8 \%$ \\
\hline $\begin{array}{c}\text { Manufacture of motor vehicles, trailers and } \\
\text { semi-trailers }\end{array}$ & $4.7 \%$ \\
\hline Manufacture of textiles & $4.2 \%$ \\
\hline Others & $32.9 \%$ \\
\hline
\end{tabular}

\subsection{Data Analysis}

For data analysis, Social Network Analysis (SNA) method was used [23, 24]. According to the previous researches which show that existence of ecosystems is a prerequisite for application of digital servitization, this research applies network analysis. SNA is the analysis which measures relations between actors in the networks (i.e. the use of traditional and digital services in the manufacturing firms) [25]. The descriptive statistics uses only the mean value of the use, while SNA method measures relations between firms in the ecosystems. In this research, SNA shows the ecosystem of manufacturing firms in transition economies (i.e. Republic of Serbia). The network shows the influence between manufacturing sectors in the way how firms use traditional and digital services. SNA method was often used by researchers in social sciences [23]. However, in the last decade, SNA starts to be used in the research of manufacturing such as logistics, service business models, cloud production, and others. For the data visualization, graphs were used (see Fig. 2 to Fig. 6), and for the rank of traditional and digital services, eigenvector was used (see Tab. 3, Tab. 4). On the graphs, industry sectors are presented with red circles according to NACE Rev 2.2 classification. With the blue squares, authors labelled traditional and digital services with a combination of letters and numbers ranging from TU1 to TU8 and from DU1 to DU5 where the traditional services correspond to the following: TU1 - Installation, start-up, TU2 - Maintenance and repair, TU3 - Training, TU4 - Remote support for clients, TU5 Design, consulting, project planning, TU6 - Software development, TU7 - Revamping or modernization, and TU8 Take-back services. Digital services correspond to the following: DU1 - Web-based offers for product utilization, DU2 - Web-based services for customized product configuration or product design, DU3 - Digital (remote) monitoring of operating status, DU4 - Mobile devices for diagnosis, repair or consultancy, and DU5 - Data-based services based on big data analysis. Additionally, in the networks authors take value 0 in case there is no network tie between manufacturing firms and use of services, and take value 1 where there is the network tie between manufacturing firms and use of traditional or digital services. These values are input for the eigenvector analysis of the ecosystem of manufacturing firms from the Republic of Serbia.

\section{RESULTS}

First, using the SNA method via graphs, the authors presented the use of traditional and digital services in the manufacturing sector of the Republic of Serbia between 2015 and 2020. Fig. 2, Fig. 3, and Fig. 4 present the use of traditional services in the manufacturing firms.

According to the presented graphs and the use of traditional services in manufacturing firms, Tab. 3 will present the eigenvector value for services in the period from 2015 to 2020 . Tab. 3 shows that manufacturing firms made the biggest growth in the use of revamping and modernization from 2015 to 2020 . On the other hand, firms make the biggest drop in the use of software development. All other traditional services make some oscillation but similar effect on the ecosystems of manufacturing firms. Fig. 5 and Fig. 6 present the use of digital services in manufacturing firms.

Table 3 Results of eigenvector for traditional services

\begin{tabular}{|l|c|c|c|}
\hline List of services & $\begin{array}{c}\text { Eigenvector } \\
2015\end{array}$ & $\begin{array}{c}\text { Eigenvector } \\
2018\end{array}$ & $\begin{array}{c}\text { Eigenvector } \\
2020\end{array}$ \\
\hline TU1 & 0.422 & 0.398 & 0.421 \\
\hline TU2 & 0.506 & 0.488 & 0.442 \\
\hline TU3 & 0.459 & 0.480 & 0.406 \\
\hline TU4 & 0.446 & 0.271 & 0.330 \\
\hline TU5 & 0.168 & 0.476 & 0.327 \\
\hline TU6 & 0.199 & 0.122 & 0.081 \\
\hline TU7 & 0.206 & 0.204 & 0.451 \\
\hline TU8 & 0.215 & 0.129 & 0.193 \\
\hline
\end{tabular}

According to the presented graphs of the use of digital services in manufacturing firms, Tab. 4 presents the eigenvector value for services in the period from 2018 to 2020 . 


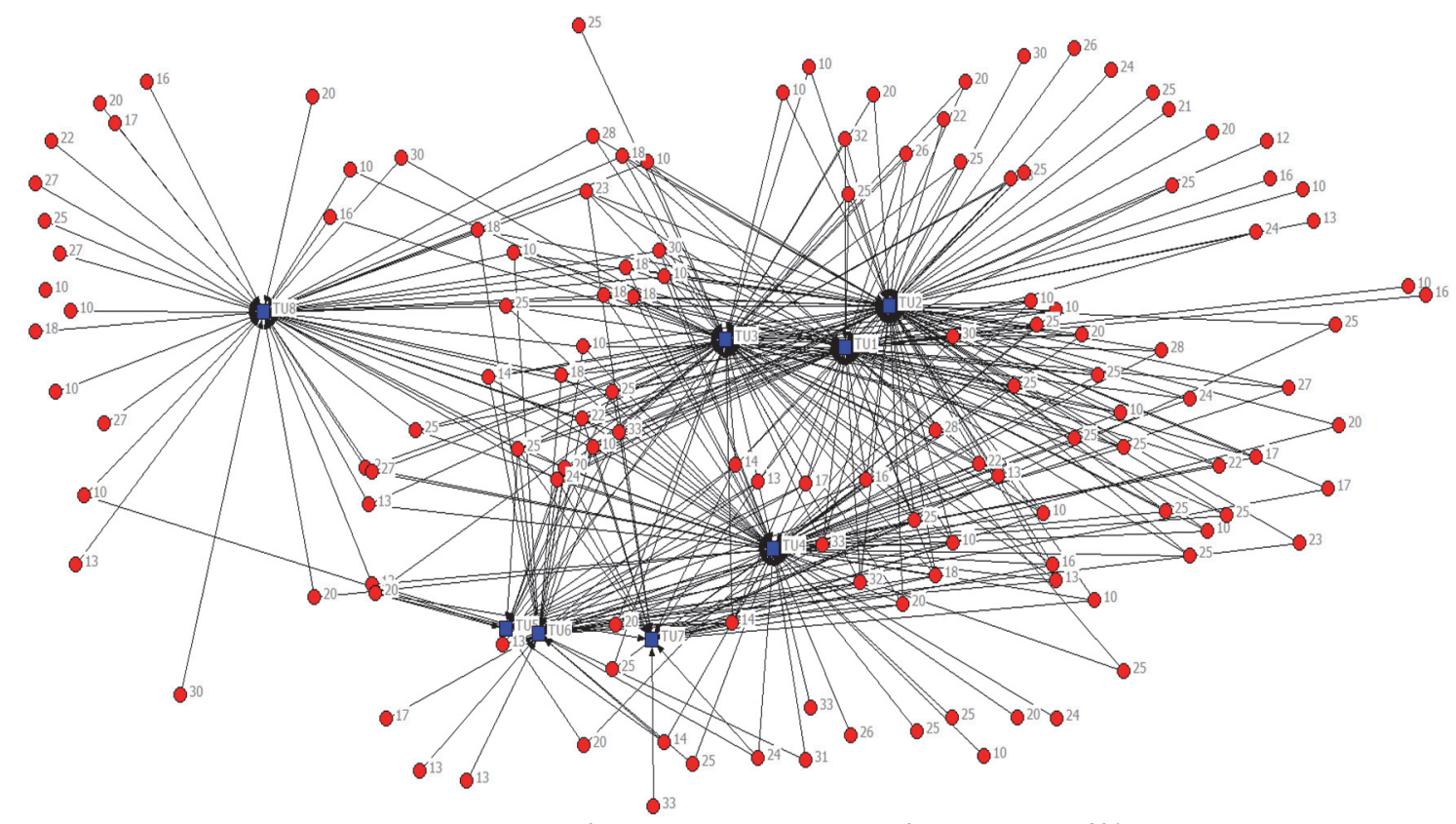

Figure 2 The use of traditional services in the manufacturing sector in 2015

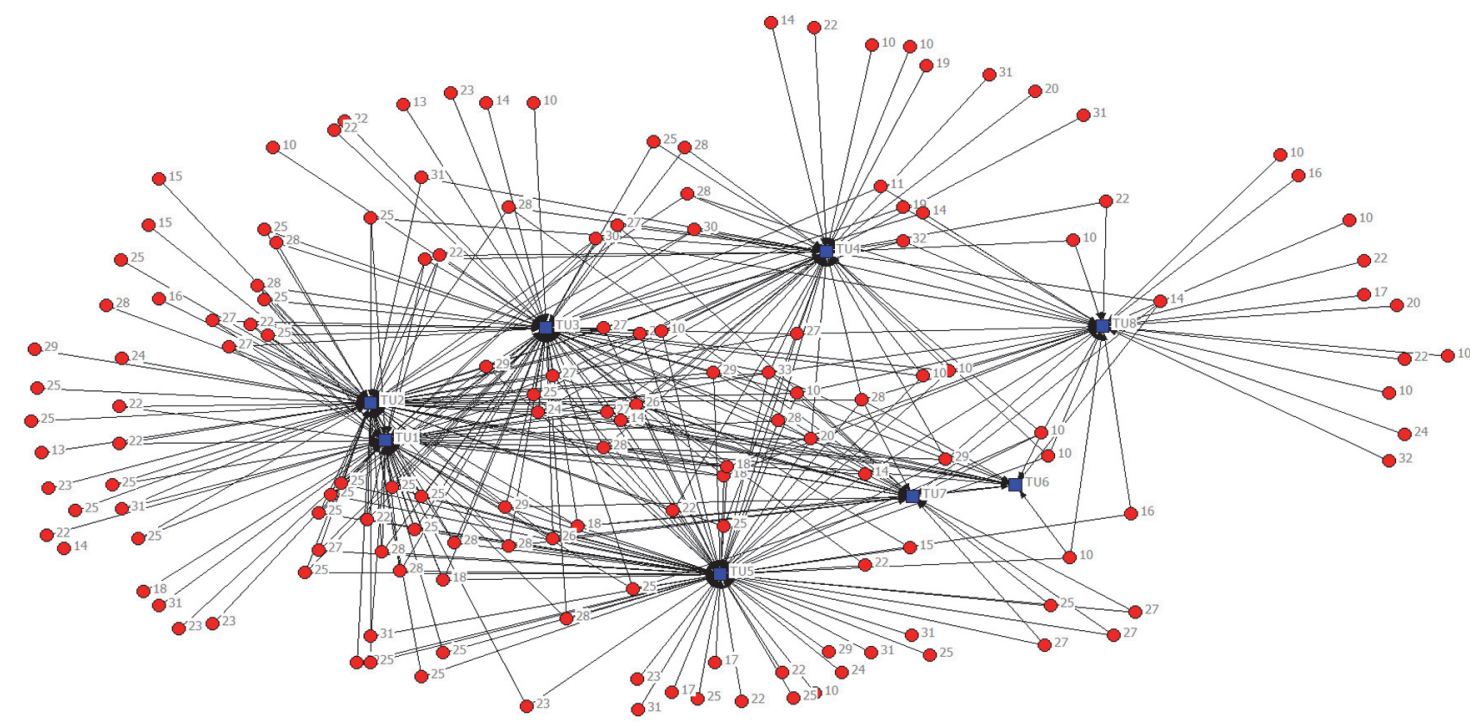

Figure 3 The use of traditional services in the manufacturing sector in 2018

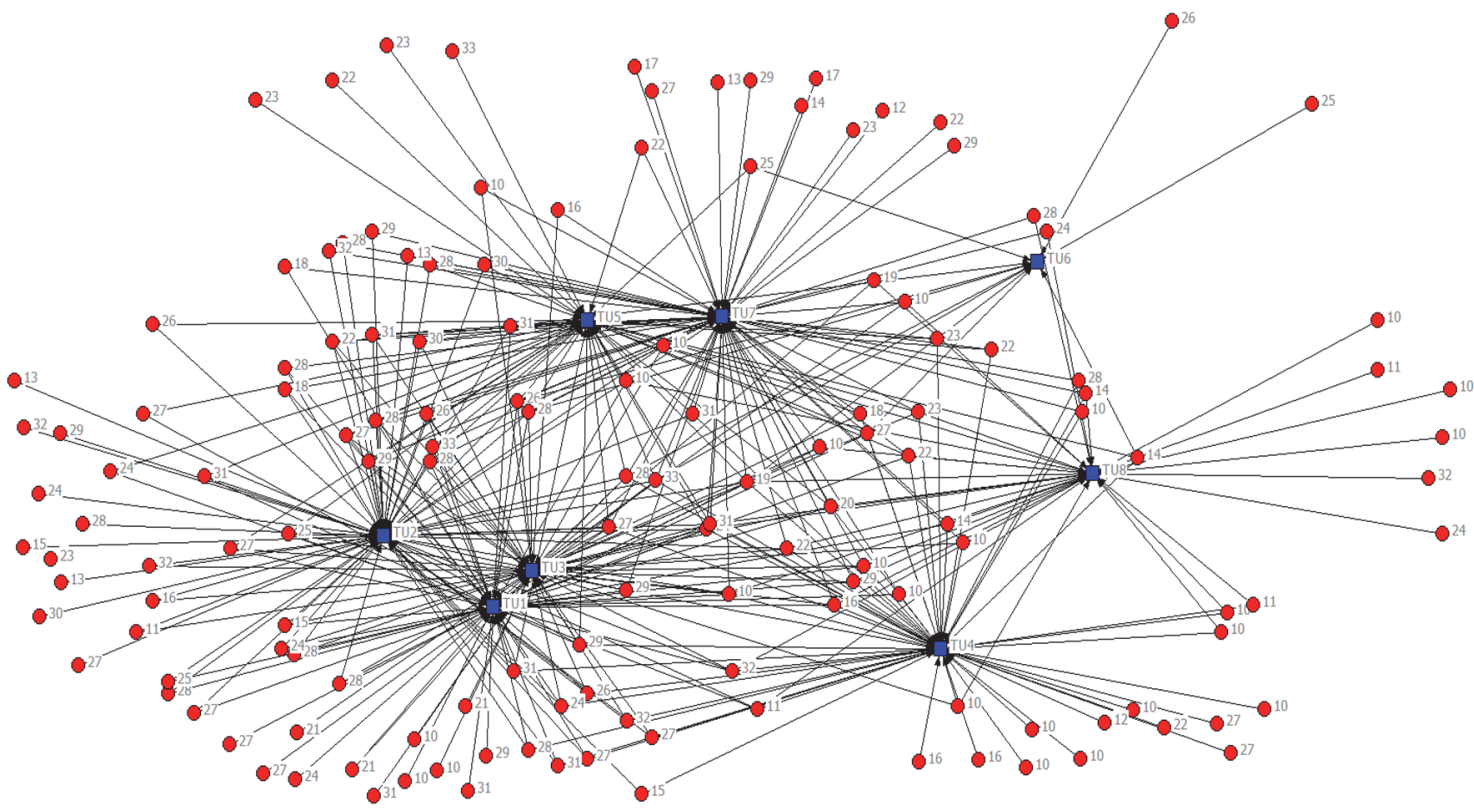

Figure 4 The use of traditional services in the manufacturing sector in 2020 


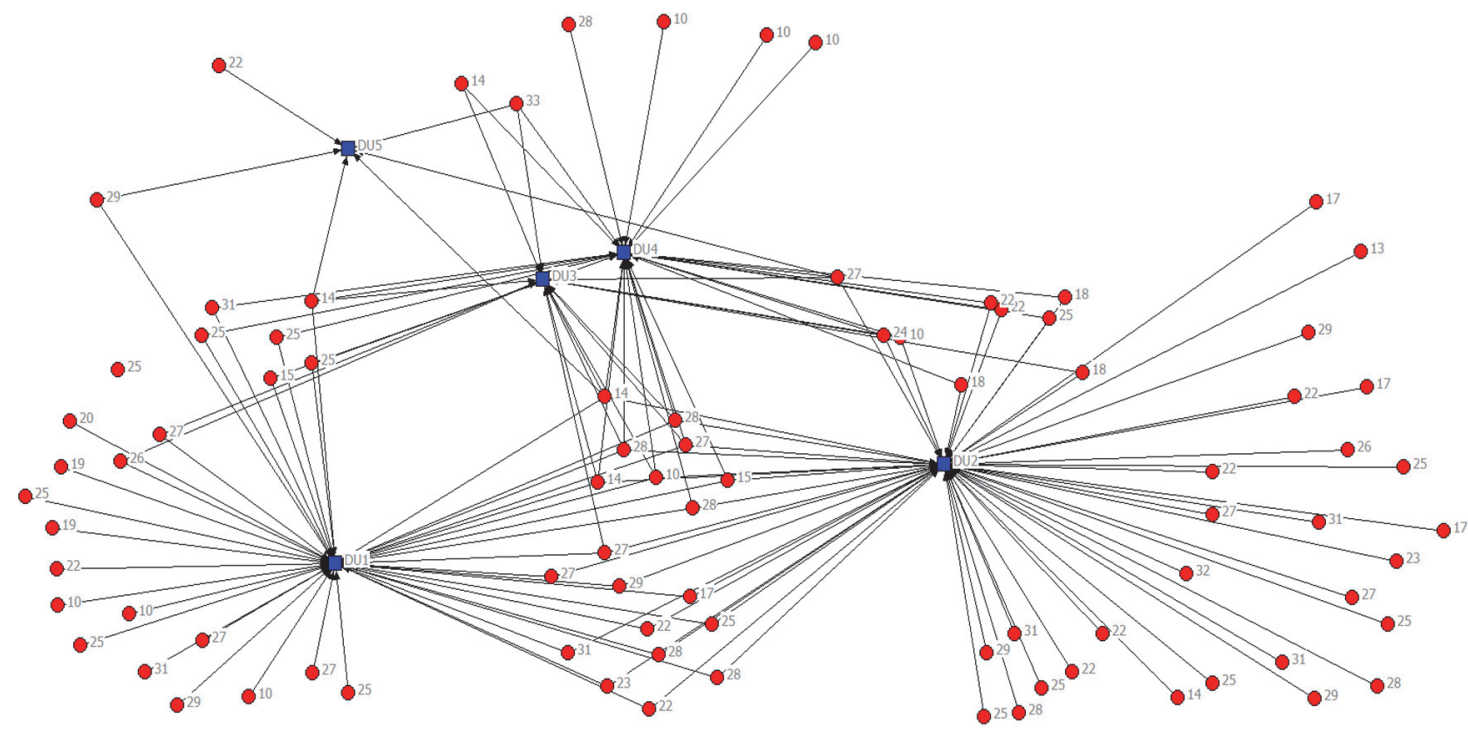

Figure 5 The use of digital services in the manufacturing sector in 2018

Table 4 Results of eigenvector for digital services

\begin{tabular}{|c|c|c|}
\hline List of services & Eigenvector 2018 & Eigenvector 2020 \\
\hline DU1 & 0.528 & 0.667 \\
\hline DU2 & 0.695 & 0.495 \\
\hline DU3 & 0.400 & 0.449 \\
\hline DU4 & 0.269 & 0.254 \\
\hline DU5 & 0.073 & 0.208 \\
\hline
\end{tabular}

Tab. 4 shows that manufacturing firms make the biggest growth in the use of digital services based on big- data analysis, with eigenvector increase from 0.073 to 0.208 and the growth of about $300 \%$. All other digital services make some oscillation in the eigenvector value but with a similar effect on the ecosystems of manufacturing firms. Moreover, the results from the last two years show that the use of digital services has made big progress according to the situation from 2015 when they were used only by some firms.



Figure 6 The use of digital services in the manufacturing sector in 2020

\section{DISCUSSION}

\subsection{Theoretical Implications}

From a theoretical perspective, the research confirms previous findings, which show the increase in the use of traditional and digital services in manufacturing firms [4]. Moreover, the results show that digital services make a higher increase rate than traditional services in manufacturing firms. These results confirm findings that show the transformation from product-service systems to the digitalized product-service systems [27]. For RQ1 (Which traditional services make the highest effect on the ecosystem of manufacturing firms?), Fig. 2, Fig. 3, Fig. 4 show that revamping or modernization make the biggest progress in the use of traditional services by manufacturing firms. Furthermore, these findings show that services such as installation, start-up, maintenance, and repair, training, and revamping or modernization of products have the highest effect on the ecosystems of manufacturing firms. These results confirm that services that are based on product characteristics have a key role in the manufacturing firms from transition economies [13, 12]. On the other side, software development that is not related to product characteristics has the highest drop in the use of 
traditional services by manufacturing firms. This confirms that firms from transition economies are not aware of the use of services that are not related to the product characteristics [5].

For RQ2 (Which digital services make the highest effect on the ecosystem of manufacturing firms?), Fig. 5 and Fig. 6 show that digital services based on big-data analysis make the biggest progress in the use by manufacturing firms. These results confirm the previous findings, which show that digital technologies are the triggers for the digital transformation of manufacturing firms [26-28]. Furthermore, the results show that webbased offers for product utilization, web-based services for customized product configuration or product design, and digital monitoring of operating status have the highest effect on the manufacturing firms from transition economies. These findings confirm that digital services, which are related to product characteristics, have a higher effect than services that are not related to product characteristics [16]. The results of both research questions show that manufacturing firms from transition countries do not understand the awareness of the services for manufacturing firms. However, the results of the measures of network density show that manufacturing firms are in the process of transformation from offer of traditional to digital services. From one side, network density for traditional services in 2018 had a value 0.214 and in 2020 0.285 . On the other side, network density for digital services in 20180.122 and in 2020 0.200. These values show high increase in the use of digital services between manufacturing firms from the period of 2 years. Moreover, these results suggest to authors that digital services could be triggers for the construction of ecosystems of manufacturing firms.

\subsection{Practical Implications}

This research presented data from the manufacturing sector of the transition economy during the five years. The results indicate that production managers from transition economies in many firms involve only the services, which are related to products. Unlike, the use of traditional services, which are not related to products, are on a very low level. However, the digital services, which involve advanced technologies, make the biggest growth in the use by manufacturing firms from transition economies (i.e. Republic of Serbia). This information could help production managers to involve more digital technologies such as virtual or augmented reality, artificial intelligence, or others in the offer of their products. These digital technologies could support traditional services such as maintenance, repair, or training which are offered along with physical products. Moreover, the use of digital technologies reduces the cost of the use of traditional services. Digital services have less unit cost than traditional services. Furthermore, digital services enable manufacturing firms to make ecosystems via digital platforms. The ecosystems could provide a new business environment for manufacturing firms. Additionally, this new environment can help manufacturing firms from transition economies to increase their competitivity on the global market. With the application of advanced technologies in manufacturing firms production managers can create new digital services which are necessary for building customer relationships. Finally, a better relationship with customers will increase manufacturing firm performance.

\section{CONCLUSION}

This research investigates the role of digital servitization in transition economies. Moreover, this study involves the SNA method in the research of digital servitization. The practical and theoretical implications show which traditional and digital services make the highest impact on the ecosystem of manufacturing firms. During the period from 2015 to 2020 results show that manufacturing firms from transition economies increased the use of digital services by $20 \%$. Furthermore, findings show that revamping and modernization make the highest impact on the ecosystem of manufacturing firms between traditional services. On the other side, digital services based on Big data analysis show the biggest increase in the use from manufacturing firms with a growth of $300 \%$. However, the use of traditional and digital services in the manufacturing sector of the Republic of Serbia is under the average values for developed countries (e.g. USA or UK). The results indicate that digital services could be the triggers for manufacturing firms to improve their servitization process. Additionally, the application of digital services in manufacturing firms of transition economies could be a driver for approaching developed economies. The main difference in the GDP structure of more or less developed countries is in the added value from services. The developed countries have about $70 \%$ added value from services in GDP, unlike transition economies which have about $50 \%$ added value from service GDP. In this way, we can conclude that innovation via digital solutions for customers is one of the most important factors for the development of transition economies. The findings indicate that manufacturing firms from transition economies have a lot of space for improvement in their use and understanding of significance from digital servitization for their economic development.

The limitations of this research are in the sample size. The authors use the data-sets from the Republic of Serbia to show the situation in transition economies. Future research could make comparative analysis for more transition economies to show the role of digital servitization for manufacturing firms. Moreover, future research needs to give new knowledge why and how some of these services traditional and digital are used in manufacturing firms. Accordingly, future research should compare the maturity models for digital servitization in developing and developed countries. While the current research investigates the use of traditional services in the period from 2015 to 2020 , a new longitudinal approach could give answers to how the Covid-19 pandemic influences the use of digital servitization.

\section{REFERENCES}

[1] Neely, A., Benedetinni, O., \& Visnjic, I. (2011). The servitization of manufacturing: Further evidence. 18th European Operations Management Association Conference, $1-9$. 
[2] Raja, J. Z. \& Frandsen, T. (2017). Exploring servitization in China: Challenges of aligning motivation, opportunity and ability in coordinating an external service partner network. International Journal of Operations \& Production Management, 37(11), 1654-1682. https://doi.org/10.1108/IJOPM-12-2015-0755

[3] Li, L. (2018). China's manufacturing locus in 2025: With a comparison of "Made-in-China 2025" and "Industry 4.0." Technological Forecasting and Social Change, 135, 66-74. https://doi.org/10.1016/j.techfore.2017.05.028

[4] Mastrogiacomo, L., Barravecchia, F., \& Franceschini, F. (2019). A worldwide survey on manufacturing servitization. The International Journal of Advanced Manufacturing Technology, 103(9-12), 3927-3942. https://doi.org/10.1007/s00170-019-03740-z

[5] Marjanovic, U., Lalic, B., Medic, N., Prester, J., \& Palcic, I. (2020). Servitization in manufacturing: Role of antecedents and firm characteristics. International Journal of Industrial Engineering and Management, 2, 133-144. https://doi.org/10.24867/IJIEM-2020-2-259

[6] Marjanovic, U., Rakic, S., \& Lalic, B. (2019). Digital Servitization: The Next "Big Thing" in Manufacturing Industries. In F. Ameri, K. E. Stecke, G. von Cieminski, \& D. Kiritsis (Eds.). Advances in Production Management Systems. Production Management for the Factory of the Future, 566, 510-517. https://doi.org/10.1007/978-3-030-30000-5_63

[7] Rakic, S., Pavlovic, M., Marjanovic, U. (2021) A precondition of sustainability: Industry 4.0readiness. Sustainability, 13(12), $6641 \quad$ (2021). https://doi.org/10.3390/su13126641

[8] Lalic, B., Rakic, S., \& Marjanovic, U. (2019). Use of Industry 4.0 and Organisational Innovation Concepts in the Serbian Textile and Apparel Industry. Fibres \& Textiles in Eastern Europe, 27(3), 10-18. https://doi.org/10.5604/01.3001.0013.0737

[9] Medic, N., Anisic, Z., Lalic, B., Marjanovic, U., \& Brezocnik, M. (2019). Hybrid fuzzy multi-attribute decision making model for evaluation of advanced digital technologies in manufacturing: Industry 4.0 perspective. Advances in Production Engineering \& Management, 14(4), 483-493. https://doi.org/10.14743/apem2019.4.343

[10] Martín-Peña, M. L., Sánchez-López, J. M., \& Díaz-Garrido, E. (2019). Servitization and digitalization in manufacturing: The influence on firm performance. Journal of Business \& Industrial Marketing, 35(3), 564-574. https://doi.org/10.1108/JBIM-12- 2018-0400

[11] Ardolino, M., Rapaccini, M., Saccani, N., Gaiardelli, P., Crespi, G., \& Ruggeri, C. (2018). The role of digital technologies for the service transformation of industrial companies. International Journal of Production Research, 56(6), 2116-2132. https://doi.org/10.1080/00207543.2017.1324224

[12] Rusakova, E. P. \& Inshakova, A. O. (2021). Industrial and Manufacturing Engineering In Digital Legal Proceedings in the Asia-Pacific Region: A New Level of Quality Based On Data, Blockchain and AI. International Journal for Quality Research, 15(1), 273-290. https://doi.org/10.24874//JQR15.01-16

[13] Benedettini, O., Neely, A., \& Swink, M. (2015). Why do servitized firms fail? A risk-based explanation. International Journal of Operations \& Production Management, 35(6), 946-979. https://doi.org/10.1108/IJOPM-02-2014-0052

[14] Tukker, A. (2004). Eight types of product-service system: Eight ways to sustainability? Experiences from SusProNet. Business Strategy and the Environment, 13(4), 246-260. https://doi.org/10.1002/bse.414

[15] Moro, S. R., Cauchick-Miguel, P. A., \& Mendes, G. H. S. (2020). Product-service systems benefits and barriers: An overview of literature review papers. International Journal of Industrial Engineering and Management, 11(1), 61-70. https://doi.org/10.24867/IJIEM-2020-1-253

[15] Lalic, B., Marjanovic, U., Rakic, S., Pavlovic, M., Todorovic, T., \& Medic, N. (2020). Big Data Analysis as a Digital Service: Evidence Form Manufacturing Firms. In L. Wang, V. D. Majstorovic, D. Mourtzis, E. Carpanzano, G. Moroni, \& L. M. Galantucci (Eds.). Proceedings of 5th International Conference on the Industry 4.0 Model for Advanced Manufacturing, 263-269. https://doi.org/10.1007/978-3-030-46212-3_19

[16] Paschou, T., Rapaccini, M., Peters, C., Adrodegari, F., \& Saccani, N. (2020). Developing a Maturity Model for Digital Servitization in Manufacturing Firms. In Z. Anisic, B. Lalic, \& D. Gracanin (Eds.). Proceedings on 25th International Joint Conference on Industrial Engineering and Operations Management - IJCIEOM, 413-425. https://doi.org/10.1007/978-3-030-43616-2_44

[17] Sklyar, A., Kowalkowski, C., Tronvoll, B., \& Sörhammar, D. (2019). Organizing for digital servitization: A service ecosystem perspective. Journal of Business Research, 104, 450-460. https://doi.org/10.1016/j.jbusres.2019.02.012

[18] Paschou, T., Rapaccini, M., Adrodegari, F., \& Saccani, N. (2020). Digital servitization in manufacturing: A systematic literature review and research agenda. Industrial Marketing Management, 89, 278-292. https://doi.org/10.1016/j.indmarman.2020.02.012

[19] Pirola, F., Boucher, X., Wiesner, S., \& Pezzotta, G. (2020). Digital technologies in product-service systems: A literature review and a research agenda. Computers in Industry, 123, 103301. https://doi.org/10.1016/j.compind.2020.103301

[20] Bikfalvi, A., Lay, G., Maloca, S., \& Waser, B. R. (2013). Servitization and networking: Large-scale survey findings on product-related services. Service Business, 7(1), 61-82. https://doi.org/10.1007/s11628-012-0145-y

[21] Simonsson, J., Magnusson, M., \& Johanson, A. (2020). Organizing the Development of Digital Product-Service Platforms. Technology Innovation Management Review, 10(3), 37-48. https://doi.org/10.22215/timreview/1335

[22] Jager A. (2021). European Manufacturing Survey Fraunhofer Institute for Systems and Innovation Research ISI. https://www.isi.fraunhofer.de/en/themen/industriellewettbewerbsfaehigkeit/fems.html

[23] Rakic, S., Tasic, N., Marjanovic, U., Softic, S., Lüftenegger, E., \& Turcin, I. (2020). Student Performance on an ELearning Platform: Mixed Method Approach. International Journal of Emerging Technologies in Learning (IJET), 15(02), 187. https://doi.org/10.3991/ijet.v15i02.11646

[24] Borgatti, S. P., Mehra, A., Brass, D. J., \& Labianca, G. (2009). Network Analysis in the Social Sciences. Science, 323(5916), 892-895. https://doi.org/10.1126/science.1165821

[25] Aiqin, Z. \& Yusen, Z. (2020). Research on the Relationship Network in Customer Innovation Community based on Text Mining and Social Network Analysis. Tehnicki VjesnikTechnical Gazette, 27(1), 58-66. https://doi.org/10.17559/TV-20190924140134

[26] Frank, A. G., Mendes, G. H. S., Ayala, N. F., \& Ghezzi, A. (2019). Servitization and Industry 4.0 convergence in the digital transformation of product firms: A business model innovation perspective. Technological Forecasting and Social Change, 141, 341-351. https://doi.org/10.1016/j.techfore.2019.01.014

[27] Jingdong, Y., Xiao, Y., Pincheng, L., \& Quan, Z. (2020). High-Tech Service Platform Ecosystem Evolution: A Simulation Analysis using Lotka-Volterra Model. Tehnicki Vjesnik-Technical Gazette, 27(5), 1509-1518. https://doi.org/10.17559/TV-20200531152811

[28] Lopes, I., Figueiredo, M., \& Sá, V. (2020). Criticality evaluation to support maintenance management of 
manufacturing systems. International Journal of Industrial

Engineering and Management, 11(1), 3-8.

https://doi.org/10.24867/IJIEM-2020-1-248

\section{Contact information:}

Nikola ZIVLAK, PhD, Assistant Professo

University of Novi Sad, Faculty of Technical Sciences,

Trg Dositeja Obradovica 6, Novi Sad, Serbia

E-mail: nikola.zivlak@uns.ac.rs

Slavko RAKIC, PhD, Teaching Assistant

University of Novi Sad, Faculty of Technical Sciences,

Trg Dositeja Obradovica 6, Novi Sad, Serbia

E-mail: slavkorakic@uns.ac.rs

Ugljesa MARJANOVIC, PhD, Associate Professor

University of Novi Sad, Faculty of Technical Sciences,

Trg Dositeja Obradovica 6, Novi Sad, Serbia

E-mail: umarjano@uns.ac.rs

Danijela CIRIC, PhD, Teaching Assistant

University of Novi Sad, Faculty of Technical Sciences,

Trg Dositeja Obradovica 6, Novi Sad, Serbia

E-mail: danijela.ciric@uns.ac.rs

Branislav BOGOJEVIC, PhD student

(Corresponding author)

University of Novi Sad, Faculty of Technical Sciences,

Trg Dositeja Obradovica 6, Novi Sad, Serbia

E-mail: bogojevic@uns.ac.rs 